\title{
Adaptasi Strategi Gamifikasi Dalam Permainan Ular Tangga Online Sebagai Media Edukasi Covid-19
}

\author{
Hani Dewi Ariessanti ${ }^{1}$, Dian Anggraini Purwaningtyas ${ }^{2}$, Haryono Soeparno ${ }^{3}$, Togar Alam \\ Napitupulu $^{4}$ \\ ${ }^{1}$ Sistem Informasi Program Doktoral Ilmu Komputer Universitas Bina Nusantara Jakarta, \\ ${ }^{1}$ Teknik Informatika Universitas Esa Unggul Jakarta \\ ${ }^{2,3,4}$ Sistem Informasi, Program Doktoral Ilmu Komputer, Universitas Bina Nusantara \\ 1hani.burhan@binus.ac.id", ${ }^{1}$ hani.dewi@esaunggul.ac.id, ${ }^{2}$ dian.purwaningtyas@ @inus.ac.id, \\ ${ }^{3}$ haryono@ binus.edu, ${ }^{4}$ togar.napitupulu@ binus.ac.id
}

\begin{abstract}
Abstrak
Pendidikan dapat diimplementasikan melalui beragam konsep, salah satunya adalah konsep gamifikasi yang kemudian diadopsi sebagai media pembelajaran. Gamifikasi menjadikan suatu perubahan pada penggunaan media pembelajaran, yaitu dari yang "konvensional" hingga yang lebih "inovatif". Penelitian ini bertujuan mengadopsi suatu konsep gamifikasi ke dalam sebuah permainan ular tangga guna mendukung pembelajaran mengenai pemahaman tentang Covid-19. Penelitian menggunakan metode dengan model waterfall, yaitu model klasik yang sederhana dengan aliran sistem yang linier, di mana output dari setiap tahap merupakan input bagi tahap berikutnya. Hal tersebut dilakukan dengan melakukan manipulasi script program dan algoritma guna memberikan kebaharuan terhadap aturan permainan ular tangga. Konsep permainan ini diharapkan akan menarik pengguna dan memberikan dampak pemahaman yang diciptakan melalui kesenangan bermain dalam menyelesaikan tantangan. Pembelajaran ular tangga ini sendiri didesain sedemikian rupa dengan interface board yang berubah secara acak setiap kali bermain hingga basis game papan menjadi game digital yang bias diaplikasikan secara offline dan online. Permainan dikembangkan hingga tahapan mode "Online Play", yang memungkinkan pertandingan dapat dimainkan dari berbagai perangkat melalui internet. Game ini menggunakan sistem kotak yang berfungsi sebagai "lobby" dalam game, sehingga pemain secara online bisa memilih untuk bergabung atau menjadi tuan rumah game dan mengundang pemain lain melalui kode game.
\end{abstract}

Kata kunci-gamifikasi, permainanu ular tangga; Covid-19, game online, media pembelajaran digital,

\begin{abstract}
Education can be implemented through various concepts, one of which is the concept of gamification which is then adopted as a learning medium. Gamification to make a change in the use of instructional media, namely of the "conventional " to the more"innovative". This study aims to adopt a concept of gamification into a game of snakes and ladders to support learning about the understanding of Covid-19. The research method with the waterfall model, which is a simple classic model with a linear system flow, where the output of each stage is input for the next stage, this is done by manipulating program scripts and algorithms to provide novelty to the rules of the snakes and ladders game concept. will attract users and provide an impact of understanding created through the pleasure of playing in solving challenges. The learning of snakes and ladders itself is designed in such a way that the board interface changes randomly every time you play until the base board game becomes a digital game that can be applied n offline and online. The game is developed to the stages of the "Online Play" mode, which allows matches to be played from various devices via the internet. This game uses a box system that
\end{abstract}


functions as a"lobby"in the game, so online players can choose to join or host the game and invite other players through the game code

Keywords - gamification, game snakes and ladders; Covid-19, online games, digital learning media,

\section{PENDAHULUAN}

Diketahui saat ini semua negara, termasuk Indonesia sedang berjuang melawan Pandemi COVID-19. Hal tersebut berdampak terhadap semua sektor kehidupan, di antaranya yang menjadi fokus penelitian saat ini adalah sektor pendidikan. Saat ini sekolahan sebagai lembaga untuk mengadakan kegiatan belajar dan mengajar di non-aktifkan sementara hingga pandemi dalam suatu wilayah dapat diatasi/ dikendalikan. Sebagai gantinya, proses kegiatan belajar dan mengajar akan berganti menjadi pembelajaran melalui daring atau Pembelajaran Jarak Jauh (PJJ). PJJ menjadikan suatu tuntutan tenaga pendidik dan masyarakat untuk berlomba menciptakan media pembelajaran berbasis daring yang menyenangkan. Hal tersebut mendorong konsep gamifikasi untuk diimplementasikan ke dalam media pembelajaran. Hal tersebut juga menuntut peneliti melakukan kajian terhadap implementasi dari konsep gamifikasi terhadap media pembelajaran melalui penelitian awal dengan pendekatan SLR. Selanjutnya, ditemukan suatu peluang bahwasannya jenis permainan yang paling universal dari sisi aturan adalah permainan papan, ular tangga. Diperlukan suatu kebaharuan untuk melakukan modifikasi dari permainan ular tangga, salah satunya adalah menghapus stigma konvensional (kuno) dari permainan tersebut menjadi suatu permainan yang inovatif (modern).

Pembelajaran berbasis permainan memiliki keunggulan karena membuka potensi untuk partisipasi penuh siswa dalam kegiatan dengan memicu perhatian mereka pada permainan, yang berarti mereka juga memperhatikan pelajaran [5]. Pada catatan itu, kami akan mengembangkan game edukasi melalui model permainan ular tangga yang telah banyak digunakan sebagai media pembelajaran bagi siswa, seperti pembelajaran matematika[4]. Kesederhanaan permainan membuatnya mudah untuk dimodifikasi oleh para peneliti untuk mencapai tujuan tertentu, seperti penelitian sebelumnya berupaya mengenalkan ular tangga sebagai media pengenalan penyakit TBC [3].

Berdasarkan penelitian terdahulu, maka peneliti mencoba mengimplementasikan permainan ular tangga dengan memberikan konten terhadap pemahaman atas bahaya Covid-19 sebagai wujud edukasi dan persiapan mendasar untuk menghadapi situasi saat ini. Gamifikasi dapat mendorong seseorang untuk melakukan sesuatu dan meningkatkan partisipasi sosial [6]. Sehingga hal tersebut akan mendukung, bahwa seseorang yang telah menerima edukasi tentang COVID-19 diharapkan memiliki perilaku yang lebih baik dalam menyikapi suatu kondisi [1] dan suasana senang dapat turut untuk membentuk sistem kekebalan tubuh yang berpotensi membuat tubuh lebih sehat [2]. Sebuah ide sederhana tersebut, memperkuat suatu dasar bahwa gamifikasi dapat diimplementasikan saat pandemi Covid-19 ini. Itulah sebabnya fokus utama penelitian ini adalah membuat suatu eksperimen media pembelajaran berbasis sistem informasi yang didedikasikan untuk siswa guna membantu mengembangkan pengetahuan mereka tentang COVID-19. Selain itu nilai-nilai kebaharuan juga diharapkan akan muncul sebagai bagian dari inovasi dan konsep algoritma baru melalui media pembelajaran ular tangga.

Tujuan dari penelitian ini adalah untuk membuat suatu permainan yang memberikan nilai edukasi sesuai dengan implementasi konsep gamifikasi di dalam proses pembelajaran. Secara spesifik, permainan yang akan dibuat adalah suatu modifikasi dari pengembangan game edukasi Ular Tangga tentang COVID-19. Secara ilmiah, penelitian ini dapat memelopori penggunaan game untuk menjelaskan Pandemi COVID-19. Dalam penerapannya, penelitian ini akan lebih mendorong cara-cara inovatif pembelajaran dan merangkul pembelajaran berbasis game dalam sistem pendidikan yang diadopsi selama pandemi.

Kebaruan dari penelitian ini terletak pada proses digitalisasi permainan ular tangga dan penambahan algoritma dari perjalanan virus Covid-19 disertai modifikasi, agar nantinya setiap 
pemain dapat memiliki life score yang merepresentasikan nilai imun tubuh untuk terinfeksi oleh perjalanan algoritma dari virus Covid-19. Penambahan beberapa interface baru menuntut suatu penciptaan algoritma yang unik dan merupakan pengembagan lanjut. Penelitian akan dilakukan dengan menggunakan "Visual Studio Code" sebagai aplikasi utama dalam mengembangkan game dan "Photoshop" dalam mendesain aspek grafis yang merupakan tampilan dari game.

\section{KAJIAN PUSTAKA}

\section{Gamifikasi}

Gamifikasi adalah pendekatan pembelajaran menggunakan elemen-elemen di dalam game atau video game dengan tujuan untuk memotivasi para mahasiswa atau siswa dalam proses pembelajaran dan memaksimalkan perasaan nyaman dan ketertarikan terhadap proses pembelajaran tersebut, selain itu media ini dapat digunakan untuk menangkap hal-hal yang menarik minat mahasiswa dan menginspirasinya untuk terus melakkan pembelajaran [23]. Gamifikasi yang diterapkan pada media pembelajaran juga dapat memberikan pemahaman terhadap pengguna, sebab gamifikasi adalah proses dimana unit pembelajaran disajikan dalam format permainan atau menggabungkan unsur-unsur permainan [24], terutama guna mendukung upaya menjelaskan bahaya dari virus Covid-19. Beberapa penelitian terdahulu memberikan beberapa metode untuk menjelaskan potensi dari bahaya virus Covid-19, seperti menggunakan sosialisasi online[10], penjelasan tatap muka [11], hingga membuat situs web sebagai pusat media Covid-19. Namun, cara penjelasan di atas bukanlah yang paling cocok untuk siswa dan anak-anak karena kurangnya kemampuan literasi ilmiah [12].

\section{Pembelajaran Berbasis Game digital}

Konsep penerapan gamifikasi pada pendidikan sudah ada sejak lama. Keseimbangan antara unsur kesenangan menjadi daya tarik bagi pembelajaran adalah bagian utama dari konsep gamifikasi [13]. Melalui pembelajaran berbasis game digital, penelitian ini akan memanfaatkan elemen permainan yang memiliki unsur hiburan ke dalam proses pemahaman mengenai Covid-19. Dibandingkan dengan metode pembelajaran konvensional, Pembelajaran Berbasis Game membuka cakrawala kemungkinan bagi siswa untuk mempertajam kemampuan mereka yang akan relevan di abad ke-21, mis. kreativitas, kolaborasi, komunikasi, dan pemikiran kritis [15]. Selain itu, pembelajaran berbasis permainan juga meningkatkan partisipasi siswa [16], yang sangat penting untuk menentukan efektivitas dan keberhasilan proses pembelajaran [17].

Secara umum, ada dua jenis Pembelajaran Berbasis Game, yaitu "Asli" dan "Modifikasi". Game "asli" dibuat dari awal untuk tujuan tertentu, sedangkan game "Modifikasi" menggunakan sistem permainan yang ada dan mengembangkannya untuk mencapai tujuan pendidikan tertentu [14]. Dalam penelitian ini, permainan ular tangga akan dimodifikasi dan didigitalkan untuk memenuhi permintaan pendidikan tentang COVID-19.

\section{Permainan Ular Tangga Sebagai Bagian dari Gamifikasi Pendidikan}

Menerapkan permainan dalam proses pembelajaran adalah cara untuk menciptakan suasana pembelajaran yang menyenangkan dan bermakna. Penelitian terdahulu telah menyarankan agar dapat mengoptimalkan implementasi game guna membantu menciptakan suasana santai melalui kesenangan dan aktivitas yang menarik serta memberikan dukungan terhadap konstruksi pengetahuan bagi siswa [25]. 
Permainan ular tangga dapat memfasilitasi siswa untuk belajar tentang penghitungan, kehidupan, interaksi dan sosialisasi. Di dalam permainan, secara implisit, para siswa dapat belajar tentang naik dan turun dalam hidup atau tentang kesenangan dan masalah. Tangga mewakili "ke atas hidup dan kegembiraan ", sedangkan keberadaan ular melambangkan" itu dalam hidup atau kesulitan". Untuk membuat permainan ular tangga tidak hanya menyenangkan tetapi juga bermakna dalam pengajaran pembelajaran, maka permainan ular tangga dapat dimodifikasi denganvariasi instruksi yang sesuai dengan materi tertentu [26].

Penelitian terdahulu juga menyebutkan bahwa permainan ular tangga dapat menyediakan simulasi komunitas tempat siswa dapat bekerja sama satu sama lain dalam mencapai tujuan bersama [19]. Penelitian sebelumnya memperkenalkan konsep makanan bergizi untuk taman kanak-kanak dengan menempatkan gambar-gambar makanan sehat di 'ladder square' dan makanan tidak sehat di 'snake square' [20]. Jenis lain menerapkan permainan ular tangga sebagai media pembelajaran sains untuk siswa sekolah dasar [21], hingga mengajarkan "anatomi" kepada mahasiswa [22]. Penelitian terdahulu menggunakan permainan ular tangga yang dimodifikasi adalah dengan modifikasi dasar berupa penyisipan pertanyaan ke dalam permainan [18], namun dalam penelitian ini akan dieksperimenkan dengan menambahkan pemain yang dimodifikasi dari algoritma computer dengan memperkenalkan konsep penyebaran virus Covid-19[19]. Hasil penelitian tersebut menyimpulkan bahwa semua kelompok umur dapat menuai manfaat dari pembelajaran berbasis Game terutama permainan ular tangga sekalipun telah dimodifikasi, sebab aturan dasar dari permainan berupa "maju/naik" jika terkena tangga dan "mundur/turun" jika terkena ular.

\section{METODE}

Penelitian dengan konsep gamifikasi untuk membuat aplikasi berbasis sistem informasi akan menjadikan adanya penggabungan sistem dengan menggunakan komponen-komponen yang dapat digunakan kembali, sehingga peneliti menggunakan Waterfall model. Waterfall Model merupakan model klasik yang sederhana dengan aliran sistem yang linier, di mana output dari setiap tahap membuat permainan ular tangga merupakan input bagi tahap berikutnya [27]. Model ini telah diperoleh dari proses rekayasa lainnya dan menawarkan cara pembuatan rekayasa perangkat lunak secara lebih nyata. Model ini melibatkan tim SQA (Software Quantity Assurance) dengan 5 tahapan, dimana setiap tahapan selalu dilakukan verifikasi atau testing atas kesalahan/bug yang ditemukan.

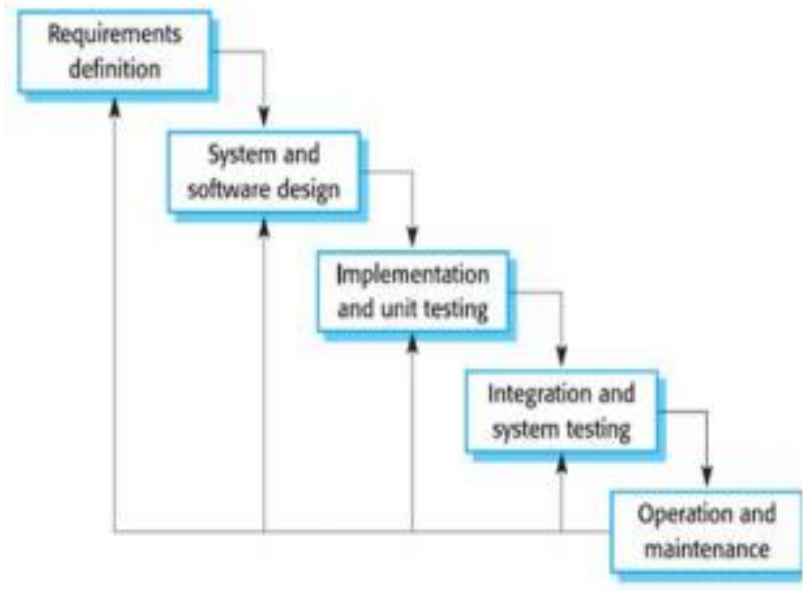

Gambar 1. Skema waterfall model [27] 
Perancangan aplikasi ini membutuhkan perangkat keras (hardware), seperti laptop ASUS AsusTek sebagai server dengan spesifikasi sebagai berikut: Processor Intel( $R$ ) Core(TM) i32330M CPU @2.20GHz;, RAM 4 GB, Harddisk Drive, DVD RW, LCD Monitor, VGA Intel dan Operasi Sistem Windows 10 dan perangkat lunak (sofware), berupa Google Chrome sebagai preview koding, Visual Studio, Photoshop, Javascript dan Android studio sebagai mengkompile koding guna pengembangan secara online.

Penelitian ini akan menjelaskan tahapan dari waterfall model dari modifikasi terhadap permainan ular tangga. Permainan papan yang digunakan dalam penelitian ini merupakan modifikasi dari papan tangga dan ular tradisional yang dibuat melalui Photoshop, kemudian dituangkan dalam java script melalui Visual Studio. Beberapa perubahan tampilan akan menyesuaikan dari kebutuhan tema, adapun tema yang diusung dalam penelitian ini adalah pemahaman atas Covid-19.

\section{HASIL DAN PEMBAHASAN}

\section{Desain Perencanaan Pembuatan Aplikasi}

Dalam merencanakan pembuatan aplikasi, maka peneliti akan berpijak dari waterfall model, sehingga langkah yang akan dilakukan adalah:

1. Tahapan perencanaan, dimulai dengan melakukan perencanaan atas program yang akan dibuat dengan penyiapan script dan algoritma permainan.

2. Tahapan analisa atas kendala, dan tujuan ditetapkan oleh hasil konsultasi dengan pengguna yang kemudian didefinisikan secara rinci dan berfungsi sebagai kesatuan tujuan membuat permainan ular tangga.

3. Tahapan berikutnya adalah perancangan sistem dengan mengalokasikan kebutuhankebutuhan sistem baik perangkat keras maupun perangkat lunak dengan membentuk arsitektur sistem secara keseluruhan. Perancangan perangkat lunak melibatkan identifikasi dan penggambaran abstraksi sistem dasar perangkat lunak dan hubungannya.

4. Tahap implementasi dan pengujian akan memuat perancangan perangkat lunak hingga direalisasikan sebagai serangkaian program atau unit program. Pengujian melibatkan verifikasi bahwa setiap unit memenuhi spesifikasinya.

5. Tahap pengintegrasian dan tes terhadap sistem akan memeriksa detil dari unit-unit individu program atau program digabung dan diuji sebagai sebuah sistem lengkap untuk memastikan apakah sesuai dengan kebutuhan perangkat lunak atau tidak. Setelah pengujian, perangkat lunak dapat dioperasikan oleh pengguna

6. Operation and maintenance adalah suatu tahapan yang umumnya merupakan tahapan yang paling panjang. Di mana sistem dipasang dan digunakan secara nyata. Maintenance akan melibatkan pembetulan kesalahan yang tidak ditemukan pada tahapan-tahapan sebelumnya, meningkatkan implementasi dari unit sistem, dan meningkatkan layanan sistem sebagai kebutuhan baru. Hal tersebut kerap dilakukan sebagai bentuk update berkala.

Hal tersebut kemudian tertuang dalam skema sebagai berikut: 


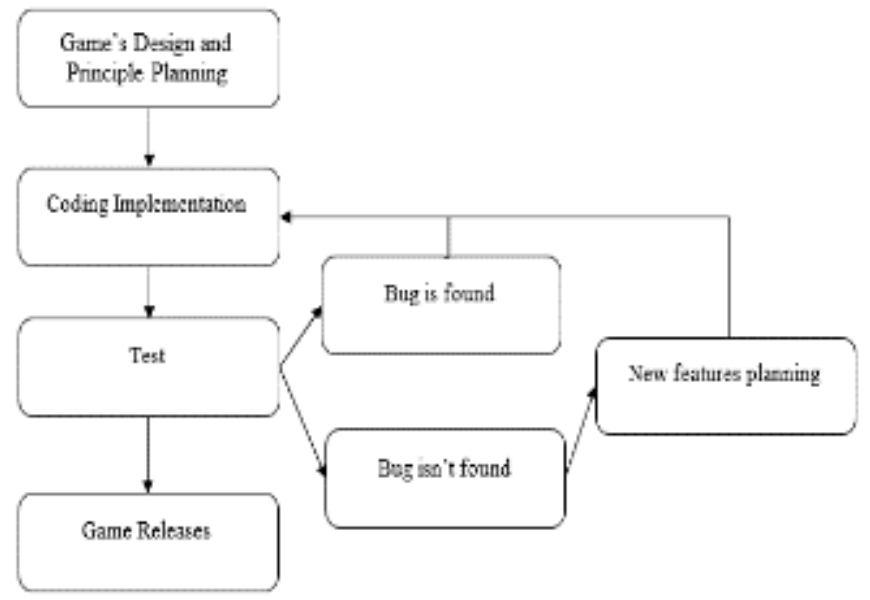

Gambar 2. Skema Waterfall model dari penelitian

Dalam hal tersebut aplikasi permainan ular tangga akan dipersiapkan sedemikian rupa dengan konsep evaluasi dari output yang merupakan input perbaikan dari sistem yang dilakukan secara bertahap.

\section{Tahap Penyiapan Algoritma Pemrograman}

Tahapan ini akan menyiapkan skrip algoritma dengan javascript, HTML, dan CSS.

Penyusunan aplikasi ini menggunakan Pure Javascript tanpa menggunakan library tambahan. Aplikasi ini bekerja layaknya ular tangga, namun bukan menghubungkan dua titik secara langsung, akan tetapi menggerakan pemain tepat ke kotak yang diatasnya. Selain itu terdapat modifikasi tambahan pada papan permainan, berupa kotak khusus. Kotak khusus ini dibagi menjadi dua, yaitu pertama merupakan kotak aktif, di mana pemain dapat bergerak maju atau mundur ketika berada di kotak tersebut dan kedua adalah kotak pasif, berupa perlakuan penambahan life score atau reward tertentu ketika berada di kotak tersebut. Dalam tampilannya kotak aktif direpresentasikan dengan gambar berupa ular, tangga, pesawat, dan kerumunan. Sementara itu kotak pasif direpresntasikan dalam gambar posko, rapid test, masker, dan cuci tangan. Kemudian terdapat immunity yang merupakan representasi dari life score yang digunakan untuk mengetahui kondisi kesehatan pemain apakah tertular atau tidak dengan nilai rentang kesehatan berupa immunity bernilai 0-100 poin.

Pada proses pembuatan ini di bentuk function, variable dan array yang akan digunakan, function merupakan kumpulan statement yang diberikan ke komputer dengan memasukan input dan menghasilkan output, sedangkan statement merupakan perintah seperti if dan loop. Input dan output yang digunakan dapat berupa variable (Memiliki satu nilai), atau array (memiliki banyak nilai). Variable pada aplikasi ini akan digunakan sebagai config dan buffer. Sedangkan array digunakan untuk menyimpan data pemain dan papan. Terdapat dua function utama, yaitu setup (yang dilakukan hanya sekali saat awal program) dan loop (dilakukan berulang kali sampai diperintahkan berhenti).

Array pertama yang dibuat adalah array papan pada function setup. Function yang digunakan akan diberi input variable config seperti asset, ukuran papan, dan banyaknya kotak khusus diam serta kotak khusus menggerakan. Function pertama yang ada didalam function setup adalah function block yang meghasilkan output posisi setiap kotak yang dihubungkan index setiap kotak. Index dibuat untuk membantu mengetahui posisi pemain. Kemudian function untuk memilih kotak khusus dipanggil untuk menentukan kotak mana yang merupakan kotak khusus. Juga terdapat function board yang berfungsi menggambar kotak serta kotak khusus pada papan dengan index yang dibuat sebelumnya. 
Selanjutnya adalah pembuatan pemain dengan menggunakan array pada function setup, lalu menggambarnya dengan function loop (karena posisi pemain akan diperbarui berulang kali). Pada function setup dibuat array yang berisi index 0 , yang artinya semua pemain berada di kotak 1 (karena komputer menghitung mulai dari 0). Serta dibuat array yang memuat status pemain. Function loop akan digunakan untuk memerintahkan program agar dapat menggerakan pemain ke index yang dituju. Index yang dituju didapat dari sebuah function yang dijalankan setelah pemain menekan tombol.

Terdapat dua macam tombol, yaitu tombol stay dan roll. Tombol stay artinya pemain tetap berada pada index yang sama dan statusnya tidak akan berpengaruh, kecuali immunity yang bertambah. Kemudian tombol roll artinya program akan menjalankan function yang memilih angka random lalu menambahkan angka tersebut ke index pemain.

Untuk lebih lengkapnya terinci sebagai berikut :

1. Roll

a. Pemain melempar dadu

b. Algoritma komputer menggerakan pemain dengan function loop

c. Algoritma komputer mengecek apakah pemain berada di kotak aktif. Jika berada di kotak aktif, maka untuk detailnya sebagai berikut :

1) Ular $\rightarrow$ Pemain turun satu lantai

2) Tangga $\rightarrow$ Pemain naik satu lantai

3) Kerumunan $\rightarrow$ Pemain dipindahkan ke dua kotak di dalam virus (hal tersebut menganalogikan bahwa berkerumun dapat berpotensi besar terpapar Covid-19)

4) Pesawat $\rightarrow$ Pemain dipindahkan dua kotak di depan virus (hal tersebut menganalogikan bahwa kegiatan bepergian dari satu wilayah ke wilayah lain dapat beresiko tertular Covid-19)

Kemudian komputer menghitung tujuan kotak dari pemain tersebut, namun apabila tujuannya ular atau tangga, maka diganti menjadi lebih satu atau kurang dengan maksud pemain akan berada bukan di kotak aktif

d. Algoritma komputer menggerakan pemain dengan menggunakan function loop

e.Pemain sampai ke kotak tujuan

f. Apabila berada di kotak pasif, maka detil instruksi pemrogramannya adalah sebagai berikut:

1) Posko, memberikan info box berisi informasi immunity pemain dengan syarat sebagai berikut

a) Immunity $0 \rightarrow$ Terinfeksi, serta mengisolasi pemain sebanyak tiga putaran, yaitu berada dalam kondisi stay.

b) Immunity 1-20 $\rightarrow$ OTG

c) Immunity $21-40 \rightarrow \mathrm{PDP}$

d) Immunity 41-60 $\rightarrow$ ODP

e) Immunity 61-99 $\rightarrow$ ODR

f) Immunity $100 \rightarrow$ Tidak terpapar

2) Rapid test, memberikan info box berupa pop up dalam tampilan berisi informasi immunity pemain dengan syarat sebagai berikut

a) Immunity $0 \rightarrow$ Reaktif

b) Immunity 1-100 $\rightarrow$ Tidak reaktif

3) Masker, memberikan pemain status true pada masker untuk pemain tersebut yang berfungsi mengurangi dampak penularan virus

4) Cuci tangan, menambah immunity pemain

5) Komputer menghitung status immunity yang dimiliki oleh pemain, dan apabila pemain memakai masker dampaknya akan dikurangi $80 \%$, jika 
6) Berada dalam kotak yang telah terkontaminasi virus, virus merupakan pemain yang hanya bergerak secara konstan, semua kotak yang dilewatinya akan terkontaminasi virus

7) Dekat dua kotak dengan pemain yang terinfeksi atau berstatus OTG

g. Giliran pemain berikutnya, dan algoritma computer akan melakukan perulangan membaca instruksi roll dari awal kembali.

2. Stay

Tombol stay artinya pemain tidak memilih tombol roll (memilih tidak mengocok dadu). Tombol stay merupakan improvisasi guna merepresentasikan, jika tombol stay ditekan, maka pemain tetap di kotak yang sama, namun Immunity pemain akan bertambah 5. Kemudian algoritma computer akan membaca untuk giliran pemain selanjutnya.

Berikutnya adalah menyusun script HTML. HTML merupakan struktur web yang digunakan untuk program ini, jadi program ini dapat dimainkan di browser. Untuk memungkinnya dapat berjalan di semua resolusi layar, maka dibuat 〈div〉 yang menggunakan style transfrom scale yang skalanya berubah setiap perubahan resolusi window. Pada html juga ditulis object yang tidak berubah ubah seperti button atau text. Object ini dapat diganti bentuk dan desainnya, namun untuk memudahkan desain, maka dibuatlah program file CSS.

CSS disini digunakan untuk mendesain struktur html yang telah dibuat. Positioning menggunakan bantuan CSS. Selain itu terdapat fitur CSS yang memungkinkan pembuatan animasi, seperti saat button hover atau fade in/out.

Prinsip tersebut kemudian diskemakan menjadi alur sebagai berikut:

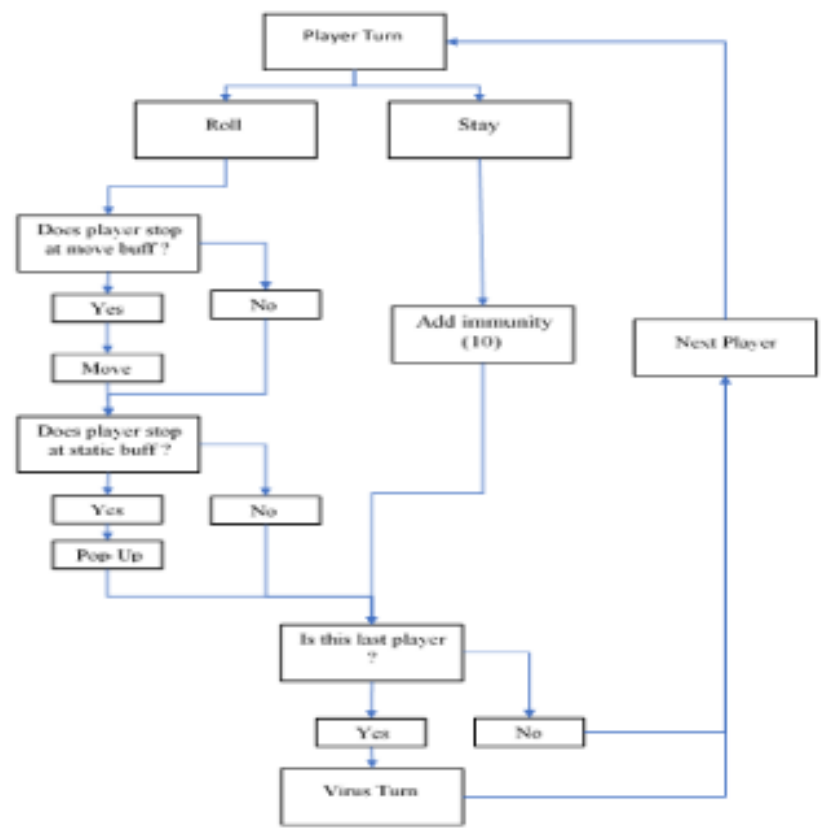

Gambar 3. Skema Alur Giliran Pemain

\section{Tahap Integrasi dan Evaluasi Dari Proses Output-Input Penyempurnaan Aplikasi Permainan}

Penyempurnaan aplikasi permainan ini melalui serangkaian revisi dan melakukan modifikasi dari konsep awal permainan ular tangga dengan memasukkan beberapa script algoritma dari peraturan permainan dan tampilan: 


\section{Evaluasi Dari Tahap Persiapan Tampilan}

Pada bagian ini akan menyajikan tampilan awal dari dasar permainan ular tangga. Modifikasi awal terjadi pada papan permainan melalui modifikasi ukuran tetap (10 x 10) dan penambahan fitur "dadu", "Ular" dan "Tangga". Untuk prototype awal, game hanya bisa dimainkan oleh 2 orang pemain. Permainan ini menggunakan perintah menjalankan pemain melalui "tombol" untuk melempar dadu. Selain itu, tata letak papan secara acak dapat berganti otomatis untuk setiap permainan.

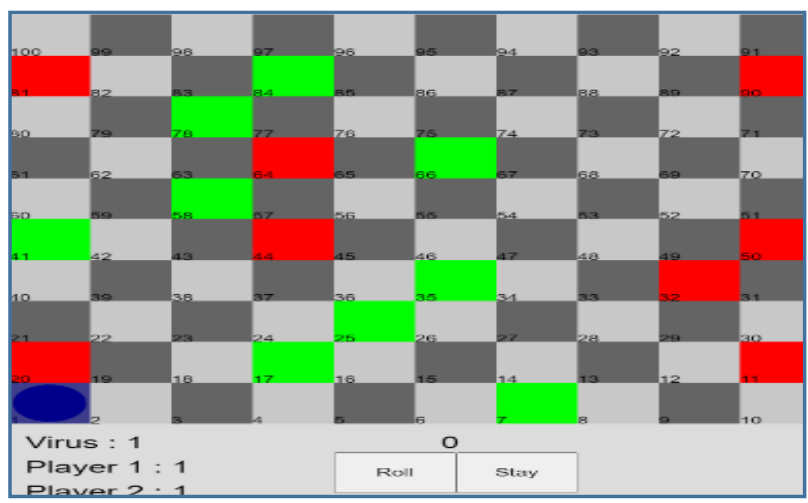

Gambar 4. Tampilan awal desain permainan

Proses berikutnya adalah melakukan evaluasi atas tampilan awal dengan menambahkan script virus yang menggunakan bahasa pemrograman untuk berjalan secara otomatis dan membuat setiap kotak yang dilaluinya menjadi kotak yang dapat memberikan infeksi kepada pemain. Hal tersebut direpsresentasikan dengan blue zone dari perjalanan virus tersebut. Setiap pemain selesai dalam 1 putaran, maka virus akan berjalan secara stabil sebanyak 3 langkah kotak, setiap yang dilalui akan menjadi kotak terinfeksi dan dapat mengurangi immunity dari pemain sebanyak 5 poin setiap putaran.

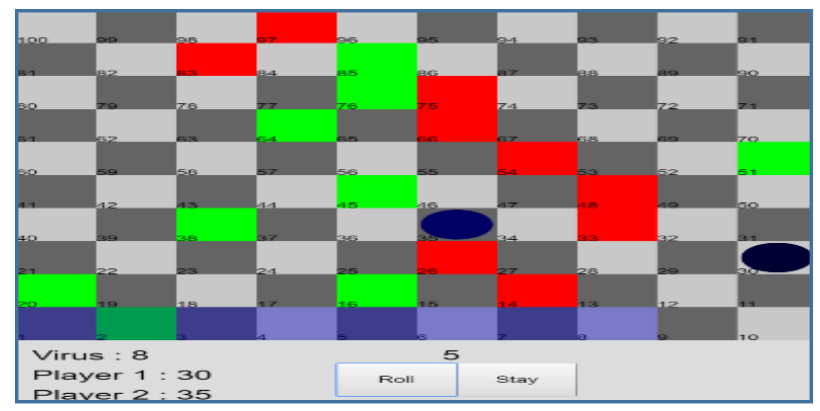

Gambar 5. Penambahan Script Virus Covid-19 yang dapat menginfeksi pemain jika berada dalam kotak yang dilalui

Kemudian peneliti melakukan revisi kembali dengan merubah layout tampilan papan agar lebih smooth. Pada tampilan ini juga diberikan script algoritma bahwa immunity pemain dapat berkurang dan jika immunity point dari pemain menjadi 0, maka pemain akan terinfeksi dan saat bertemu dengan pemain lain (berada di kotak yang sama), maka pemain lain dapat berpotensi tertular karena immunity point pemain tersebut juga akan berkurang sebesar 20 poin dalam satu putaran. Pemain yang terinfeksi adalah pemain yang immunity 
point-nya mencapai 0 dari nilai 100 . Konsep ini merepresentasikan penyebaran Covid-19 yang cepat dalam kehidupan sehari-hari dan pemain dituntut untuk menjaga jarak.

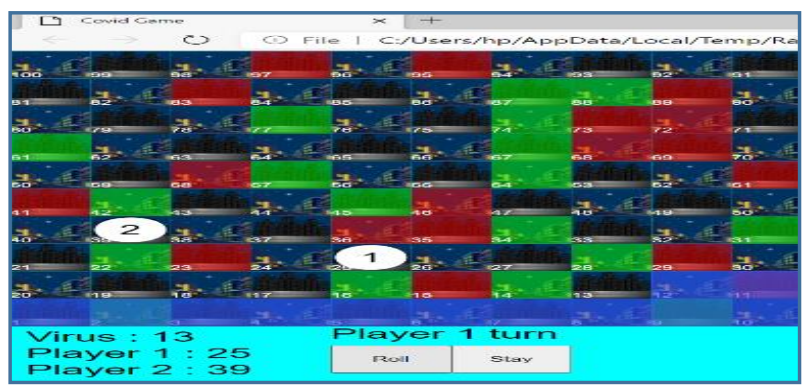

Gambar 6. Tampilan terbaru dengan tambahan kemampuan pemain menginfeksi pemain lainnya.

Dalam versi berikutnya, peneliti memperbaiki script untuk dapat dimainkan hingga 7 pemain secara bersamaan. Selain itu, menambahkan kotak aktif berupa posko bergambar seorang dokter yang merepresentasikan pemeriksaan Covid-19 melalui $P C R$ test. Jika pemain berhenti di kotak tersebut immunity point tidak akan ditampilkan, namun terdapat pop up notifikasi yang menjealaskan status riwayat pemain sebagai OTG, PDP, OTG, ODR dan Sehat jika Immunity point masih 100.

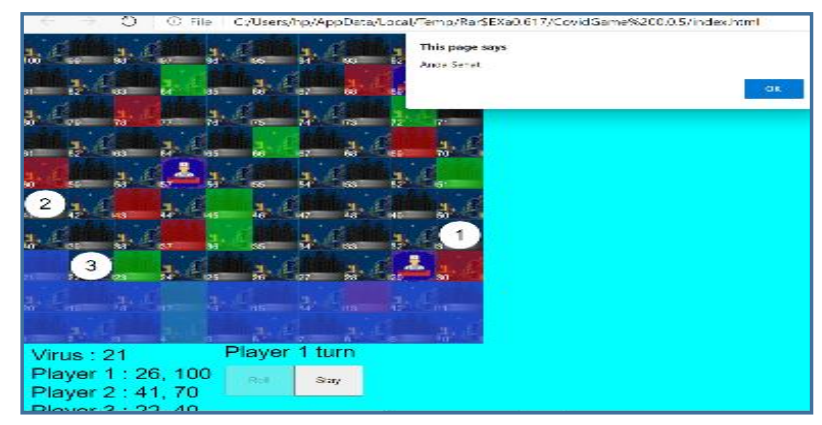

Gambar 7. Tampilan saat pemain berhenti di kotak aktif bernama posko, akan disajikan notifikasi status pemain.

Update berikutnya akan memberikan suatu perbaikan dari algoritma agar tidak terjadi crash. Pada permainan ini akan meningkatkan kewaspadaan, sebab nilai immunity point dari pemain tidak pernah ditampilkan, dan hanya bisa terlihat berdasarkan kategori status saat pemain berhenti di kotak posko.

\section{Revisi dan Update Aplikasi Permainan}

Bagian ini adalah upaya penyempurnaan aplikasi permainan untuk diujicobakan dengan penambahan beberapa komponen seperti yang disajikan pada bagian metode penelitian, yaitu kotak aktif dan kotak pasif. 


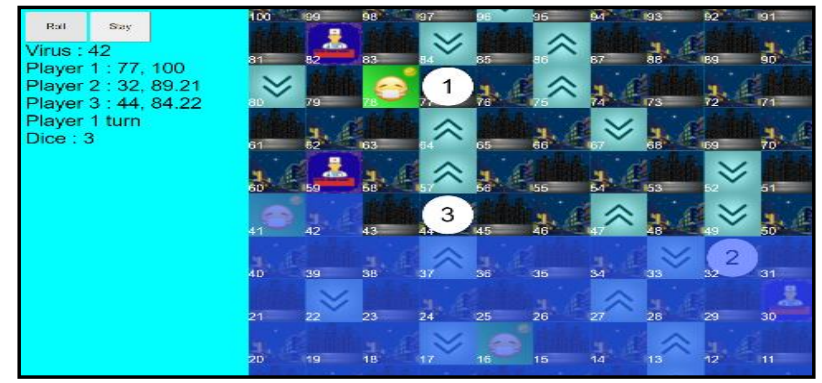

Gambar 8. Penambahan Kotak Aktif dan Kotak Pasif Dalam Permainan

Guna meningkatkan pemahaman terhadap bahaya Covid-19 mempertahankan nilai-nilai rasional, maka ditambahkan kotak aktif Rapid Test. Kotak rapid test ini tidak sama dengan kotak aktif Posko, di mana kotak rapid test hanya akan membaca immunity point dengan nilai 0 dengan kategori reaktif dan 1-100 sebagai bagian tidak reaktif. Hal tersebut, menjadikan pemain agar tetap waspada bahwasannya bias saja nilai immunity point sudah kecil namun masih tergolong tidak reaktif. Pemilihan nilai tersebut dipertimbangkan berdasarkan keakuratan dari rapid test yang ada sehari-hari.

Selain itu, fungsi dari penambahan kotak pesawat dan kerumunan menjadikan pemain dapat mundur/ mendekati script algoritma dari perjalanan Covid-19. Hal tersebut akan menambahkan tantangan dalam bermain ular tangga dan meningkatkan kewaspadaan dari pemain.

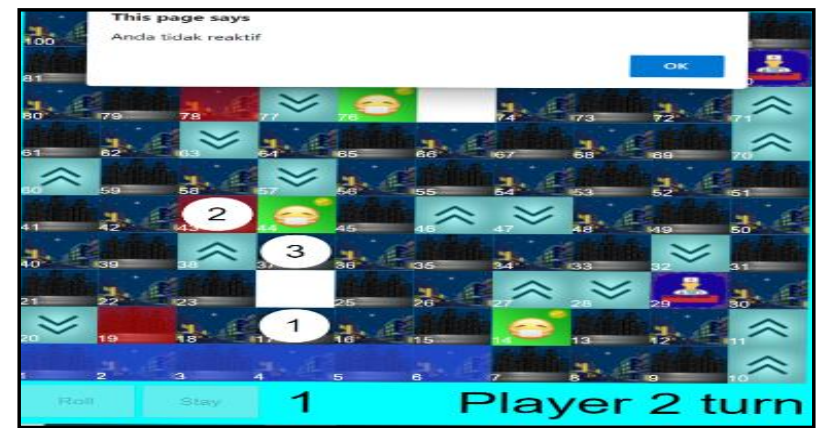

Gambar 9. Penambahan fitur kotak PCR yang hanya memberikan informasi reaktif dan tidak reaktif

Tampilan peraturan permainan sebelum permainan dimulai adalah suatu keharusan, sehingga pada tampilan awal akan diberikan panduan permainan berupa penjelasan dari ikon-ikon yang ada di papan permainan, bagaimana memulai permainan hingga bagaimana proses pemain dapat terinfeksi Covid-19.

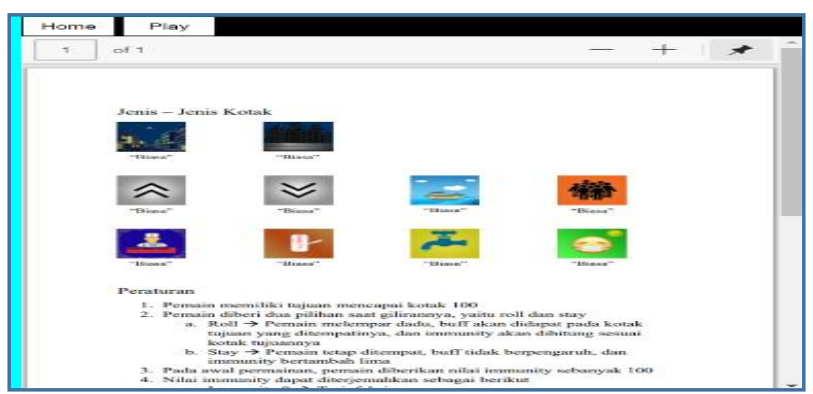

Gambar 10. Peraturan Dan Panduan Permainan Yang Muncul Pada Menu Tampilan Awal

Dalam revisi permainan berikutnya adalah kemampuan merubah tampilan papan dari $5 \times 5$, 10x10 hingga 25x25. Hal tersebut bertujuan untuk menyesuaikan jumlah pemain dan tingkat kesulitan pada setiap permainan. Pada jumlah yang banyak pemain, maka tampilan papan $25 \times 25$ akan menjadi lebih ideal, namun lebih lama untuk diselesaikan. 
Pada model permainan ini, semua pemain dapat menyelesaikan menuju garis finish (tujuan akhir), namun status pemain sebagai pemain yang terinfeksi atau sehat akan ditampilkan di akhir permainan. Sehingga hal tersebut akan meningkatkan kewaspadaan dari para pemain.

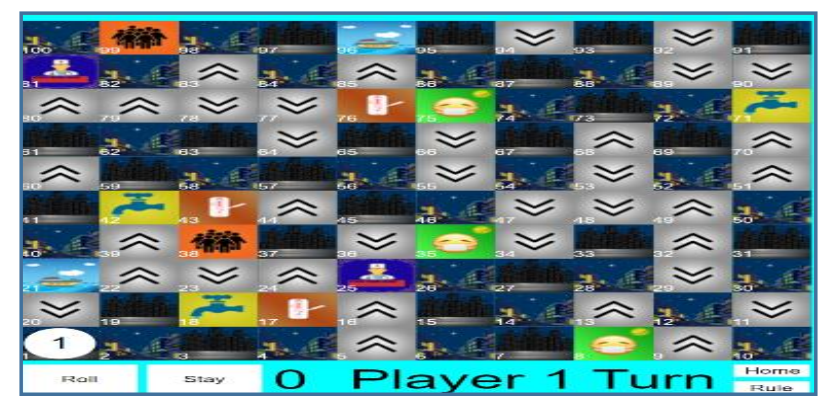

Gambar 11. Tampilan papan dapat dimodifikasi menjadi 5x5, 10x10 dan 25x25 sebagai bagian dari penyesuaian jumlah pemain.

\section{Adaptasi Permaian Ular Tangga Covid-19 Secara Online}

Pada tahap akhir, peneliti melakukan sebuah update mayor dengan mengkondisikan permainan dari offline menjadi online dengan dikemas menjadi suatu aplikasi android. Harapan saat digunakan secara online adalah, permainan akan lebih menantang dengan pemain yang belum dikenal. Oleh karenanya, tampilan dalam permainan ini menambahkan suatu bentuk "lobby" guna pemain menunggu untuk diundang atau membuat permainan baru sebagai room master.

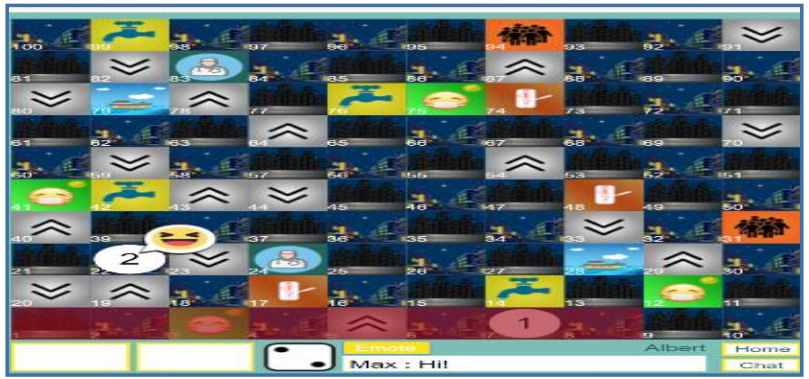

Gambar 12. Tampilan Permainan Ular Tangga Menjadi Online

Dengan menjadikan permainan ular tangga dari offline menjadi online, maka dibuatlah suatu tampilan yang berisikan script identitas pemain dan script tambahan untuk fitur chat. Chat penting digunakan untuk menghidupkan permainan dan menjadikan konsep gamifikasi secara digital dapat melibatkan interaksi sosial sesame pengguna. Pada mode online juga ditambahkan waktu jalan seorang pemain dengan batasan selama 30 detik, jika pemain tidak jalan selama 30 detik, maka sistem akan membaca pengoperasian dilakukan secara acak oleh algoritma komputer.

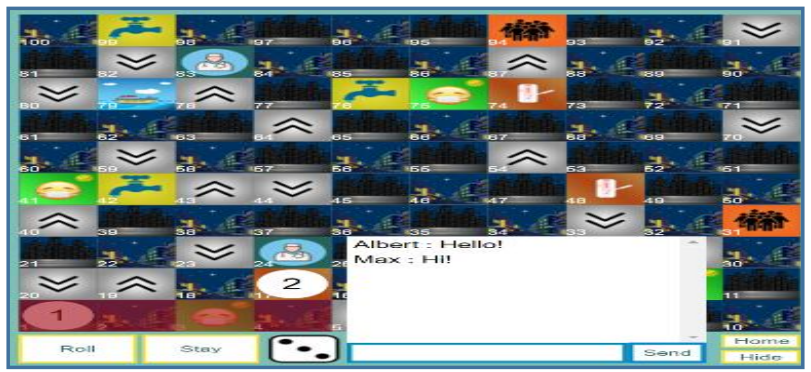

Gambar 13. Penambahan Fitur Chat Pada Permainan Ular Tangga Covid-19 


\section{PENUTUP}

Kesimpulannya, permainan ini menampilkan banyak perilaku dan hal-hal yang berhubungan dengan Pandemi Covid-19. Penelitian diharapkan bahwasannya melalui permainan, maka setiap pemain akan mendapatkan informasi dan pemahaman yang lebih baik tentang situasi pandemi saat ini, dan dapat mendorong kea rah suatu perilaku yang lebih baik terkait Pandemi COVID-19. Penelitian dapat memanfaatkan model gamifikasi melalui permainan ular tangga guna memperkenalkan bahaya pandemi Covid-19 dengan cara yang menyenangkan bagi pengguna, sehingga pemain dapat memperoleh lebih banyak pengetahuan melalui metode ini. Keterbatasan dalam penelitian ini adalah tidak adanya server sebagai perekam dan tidak adanya rank yang merupakan riwayat permainan dari pemain. Akan lebih menantang jika riwayat permainan dapat disimpan dan memiliki tingkatan rank guna menjadi daya tarik tersendiri.

\section{REFERENSI}

[1] Sari, D. P., \& 'Atiqoh, N. S. (2020). Hubungan Antara Kepatuhan Masyarakat Dengan Kepatuhan Penggunaan Masker Sebagai Upaya Pencegahan Penyakit Covid-19 di Ngronggah. Jurnal Ilmiah Rekam Medis dan Informatika Kesehatan, 52-55.

[2] Nurkholis. (2020). Dampak Pandemi Novel-Corona Virus Disiase (Covid-19) Terhadap Psikologi Dan Pendidikan Serta Kebijakan Pemerintah. Jurnal PGSD, 39-49.

[3] T. Ramakrishnan, "The Control of Tuberculosis: A Continous Game Of Snake and Ladders.", Journal Biosci, 24. 2019, hal 143-152.

[4] L Vitoria et al, "Teaching Mathematics Using Snakes And Ladders Game To Help Students Understand Angle Measurement”, Journal of Physics: Conference Series 1460, 2020.

[5] Nachiappan, D. S., Rahman, N. A., Andi, H., \& Zulkafaly, F. M. (2014). Snake and Ladder Games in Cognition Development on Students with Learning Difficulties. Review of Arts and Humanities, 217-229.

[6] Jorge Manuel, "Using Gamification To Improve Participation in Social Learning Environments", Journal Uniersity of Vigo, 2015.

[7] Hassanzadeh-Rostami, Z., Mirshekari, M., Ranjbaran, H., \& Khosravi, S. (2018). Effect of Game-Based Nutrition Education on Nutritional Knowledge of Preschool Children. International Journal of Nutrition Sciences, 50-55.

[8] Jarvis, C. I., Zandvoort, K. V., Gimma, A., Prem, K., group, C. C.-1., Klepac, P., . . . Edmunds, W. J. (2020). Quantifying the impact of physical distance measures on the transmission of COVID-19 in the UK. BMC Medicine, 1-10..

[9] Noor, F., Ayuningtyas, F., \& Prihatiningsih, W. (2020). Disaster Communications for Handling Coronavirus Disease 2019 (COVID-19) in Indonesia. International Journal of Multicultural and Multireligious Understanding, 25-35.

[10] Ausrianti, R., Andayani, R. P., Surya, D. O., \& Suryani, U. (2020). Edukasi Pencegahan Penularan COVID 19 Serta Dukungan Kesehatan Jiwa dan Psikososial pada Pengemudi Ojek Online. Jurnal Peduli Masyarakat, 2(2), 59-64.

[11] Hartati, P., \& Susanto. (2020). Peran Pemuda Tani Dalam Pencegahan Penyebaran COVID19 di Tingkat Petani (Kasus Kabupaten Malang). BASKARA, 107-112. doi:10.24853/baskara.2.2.

[12] Setiawan, A. R. (2020). Lembar Kegiatan Literasi Saintifik untuk Pembelajaran Jarak JauhTopik Penyakit Coronavirus 2019 (COVID-19). Jurnal Edukatif, 28-37.

[13] All, A., Castellar, E. P., \& Looy, J. V. (2016). Assessing The Effectiveness of Digital Game-based Learning: Best Practices. Computers \& Education, 90-103. 
[14] Stewart, J., Bleumers, L., Looy, J. V., Marien, I., All, A., \& Schurmans, D. (2013). The Potential of Digital Games for Empowerment and Social Inclusions of Groups at Risk of Social and Economic exclusion : Evidence and Opportunity of Policy. Scientific and Technical Research Reports.

[15] Qian, M., \& Clark, K. R. (2016). Game-based Learning and 21st Century Skills: A Review of Recent Research. Computers in Human Behaviour, 50-58.

[16] Hamari, J., Shernof, D. J., Rowe, E., Coller, B., Asbell-Clarke, J., \& Edwards, T. (2016). Challenging games help students learn: An empirical study on engagement, flow and immersion in game-based learning. Computers in Human Behavior, 170-179.

[17] Martin, F. (2018, March). Engagement Matters Student Perceptions on the Importance of Engagement Strategies in the Online Learning Environment. Online Learning Journal, 22(1), 206-222.

[18] Shitiq, H. A., \& Mahmud, R. (2010). Using an Edutainment Approach of a Snake and Ladder game for teaching Jawi Script. 2010 International Conference on Education and Management Technology, 228-232. doi:10.1109/ICEMT.2010.5657667

[19] Ibam, E., Adekunle, T., \& Agbonifo, O. (2018). A Moral Education Learning System based on the Snakes and Ladders Game. EAI Endorsed Transactions on e-Learning, 1-9.

[20] Hassanzadeh-Rostami, Z., Mirshekari, M., Ranjbaran, H., Khosravi, S., Faghih, S. (2018). Effect of Game-Based Nutrition Education on Nutritional Knowledge of Preschool Children. International Journal of Nutrition Sciences, 3(1), 50-55.

[21] Amin, M. L., Sulistyorini, S., \& Sugianto. (2020). The Increase of Students Science Cognitive using Snake Ladder Media. Journal of Primary Education, 68-74.

[22] Golchai, B., Nazari, N., Hassani, F., Nasiri, E., nejad, R. G., \& Jafari, Z. (2012). Snakes and ladders : a new method for increasing of medical students excitement. Procedia-Social and Behavioral Sciences, 2089 - 2092.

[23] Hsiao-Cheng Sandrine Han, "Gamified Pedagogy: From Gaming Theory to Creating a SelfMotivated Learning Environment in Studio Art", the National Art Education Association Studies in Art Education: A Journal of Issues and Research 56 (3), 2015, hal 257-267.

[24] Juho Hamari et al, "Challenging Games Help Students Learn: An Empirical Study On Engagement, Flow And Immersion In Game-Based Learning", Journal Computers in Human Behavior 54, 2016, hal 170-179

[25] Bose K and Seetso G, "Science and mathematics teaching through local games in preschools of Bostwana South Afrincan", Journal of Childhood Education 6(2), 2016 hal 19.

[26] Ulil Albab, "The Effectiveness of Snake and Ladders Game to Improve Students' Mastery of Simple Past Tense in Constructing Recount Texts "(A Quasi-Experimental Research of the English Grade Students os SMP N 2 Demak in Academic Year of 2013/2014). Journal walisongo Vol.3, No. 6706, 2014.

[27] Raharjo, Dani dan Warkim. "Prototipe Sistem Informasi Geografis Fasilitas Kesehatan di Kota Cirebon Berbasis Web." Jurnal Teknik Informatika dan Sistem Informasi Vol. 1 Nomor 3, 2015. 